\title{
The global value chain dimension of foreign direct investment flows in the agro-industrial sector of South Africa, 2003-2014
}

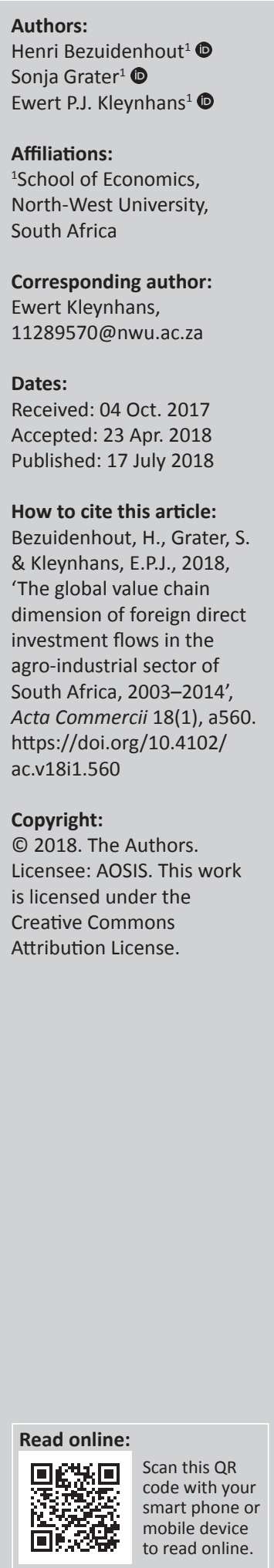

Orientation: African countries offer many investment opportunities and also urgently need global investment finance. Along the value chains of the agro-industrial sector there are many global challenges for African countries to attract foreign direct investment. This article investigates the investment flows in agro-industries and products to and from South Africa.

Research purpose: This study evaluates the nature and dimensions of the agro-industrial sector that receive investment inflows in South Africa, as well as investigating South African investment patterns into Africa.

Motivation for the study: Of particular interest is the relationship between foreign direct investment (FDI) flows, their integration into global value chains and sustainable investment options.

Research design, approach and method: Qualitative data and visual techniques using available data for the period 2003-2014 disambiguate the linkages in FDI patterns with regard to regions, industries and specific companies. Flows between regions and the specific companies are identified and studied.

Main findings: The results indicate that the United States, the United Kingdom and the Netherlands are the largest investors in South Africa, with a strong focus on agricultural input production and subsequent agro-processing industries. South African investment into Africa follows a similar, albeit narrower and more focused, pattern. The study concludes that foreign multinational enterprises are actively involved in global value chain expansion and South African firms are following suit.

Practical/managerial implications: The lack of FDI in actual agricultural crop production in Africa offers future investment opportunities.

Contribution/value-add: This study creates a better understanding of how FDI in agriculture is linked to the development of regional value chains in the Southern African region. The methodology applies a novel approach to an important field of study, of which little knowledge exists, and may contribute to the creation of wealth in the countries of the region and the welfare of its population.

\section{Introduction}

Modern production systems are evolving and continually becoming more dynamic. Scarcity of resources, and especially capital, is fundamental to economic theory, which necessitates investment funds (Arestis 1996). In Africa, this is an even larger constraint, making foreign direct investment (FDI) very important for the growth and development of the region. This study puts the relationship between various investment flows and global value chains (GVCs) in focus as it relates to the agro-industries of South Africa.

The dawn of modern technology and communication devices has enabled production processes to be divided and each section developed at a location with the most expertise and the lowest costs, enhancing profits and the creation of employment opportunities (Kleynhans \& Drewes 2008b:143). In Africa, with its high poverty levels, this is most important. Investment flows are no longer just the increasing of capital goods but a strategic decision, which necessitates much information and planning (Allard, Chen \& Kitsios 2015).

This article evaluates the nature and dimensions of the different sub-sectors that receive investment in South Africa, as well as the pattern of investment from South Africa into Africa. 
Although South Africa and other African countries receive FDI from other countries, there are also outward foreign investments (OFDI) to Africa and overseas, flowing from South Africa. This study applies qualitative data and visual techniques to disambiguate the linkages in FDI patterns. Flows between regions and the specific companies are identified and studied. Data for FDI flows are limited in availability; however, evaluation of the data from 2003 to 2014 offers interesting insights. This is intended to create a better understanding of how FDI in agriculture is linked to the development of regional value chains (RVCs) in the Southern African region.

The following section commences discussing the link between FDI and GVCs. Then, attention is given to investment trends in Africa, followed by FDI inflows to South Africa, as well as outflows from South Africa to Africa. Then the focus shifts to agriculture, first considering greenfield investments, South African mergers and acquisitions (M\&A) and then the link between South Africa's FDI inflows and outflows in agriculture. Finally, a summary and conclusions of the research are provided with some recommendations.

\section{The link between foreign direct investment and global value chains}

\section{The determinants of foreign direct investment}

Foreign direct investment is 'the process whereby residents of one country acquire ownership of assets for the purpose of controlling the activities of a firm in another country' (Moosa 2002:265). Most research in recent years has indicated that FDI has positive implications for economic growth, mostly resulting from the technology that is diffused in the local economy. New technologies and innovations are brought to the host country through FDI and, in ideal circumstances, should lead to sustainable growth and development of the local economy (Bezuidenhout \& Grater 2016:1116). This is not always the case in all sectors, and FDI can have diverse impacts in different sectors. The motivation for FDI is therefore one of the most important aspects to determine whether it will have a positive spillover into the local economy. It is therefore important to understand what drives a multinational enterprise (MNE) to invest in a specific location.

Foreign direct investment is largely driven by one of three motivations, as explained by the OLI theory (Dunning \& Lundan 2008). Here, the $O$ indicates the motivation to obtain an ownership advantage, the $L$ the advantage that the location offers and thirdly $I$ represents the advantage that internalisation offers to investors. Obtaining ownership of commodities or production processes offers a multinational company market power or better price structures, rendering them competitively advantaged above their competitors (Porter 1998). Superior location might ensure more costeffective production, while the advantage of internalisation may yield internal assets for a company's own advantage, keeping competitors out of a destination country (Bezuidenhout \& Kleynhans 2017:235).
Foreign direct investment is also motivated because companies seek resources, strategic assets, higher efficiency and markets for their operations (Dunning 2001; Dunning \& Lundan 2008). The category motivated by the search for resources occurs when an MNE invests in a specific destination for the purpose of acquiring specific resources, usually in terms of commodities and natural resources, but also other materials or labour. Market-seeking FDI is mostly driven by the need to expand the MNE's market reach, to supply for the specific local market, as well as to distribute to neighbouring countries from there. When a company is in a position to lower cost structures or obtain economies of scale through FDI, it can improve its productivity and this will motivate efficiency-seeking (Coetzee et al. 2016:155). This can also increase competitive advantage, as it can provide entrance to markets, institutions, new demand and the acquisition of factors of production and resources (Dunning 2000). Lastly, the strategy motive intends to align the investor's strategic objectives to its international competitiveness and even increase that advantage where possible (Dunning 2000; Mallampally \& Sauvant 1999).

\section{The link between foreign direct investment and value chains}

Foreign direct investment activates economic growth and trade in the less developed world, as it provides countries the opportunity to become part of GVCs and RVCs; however, most value chains remain primarily regional in nature (Timmer et al. 2014). The World Bank (2016a) explains the term 'value chains' as the different stages at which value is added to a product or service during the production process. Therefore, production is 'fragmented' to create a more competitive or cost-effective end product (Kleynhans 2016). This is not a new concept; however, in recent times, the intensity of this fragmentation and its geographical dispersion have increased (Elms \& Low 2013).

The literature on FDI and the determinants of FDI is exhaustive and well documented. Dunning and Lundan (2008), Blonigen (2005) and James (2013) provide detailed overviews. The current article's focus is, however, on the link between value chains and FDI, rather than the traditional determinants.

The concept of value chains therefore entails the value addition at different stages during production that turn raw commodities (such as minerals or agricultural products) into final products (Gurría 2012). This brings the concept of 'beneficiation' into the GVC framework, as much of the value addition occurs through outsourcing to local firms. In the mining and mineral industries in South Africa, for example, beneficiation involves the transformation of a primary product into a higher value product, which also has higher export sales values (DMR 2011). Beneficiation (adding value to the raw product), in today's global economy, can occur at any location in the world (Coetzee \& Kleynhans, 2018).

The World Bank (2016a) therefore explains that GVCs or regional RVCs lead to specialisation of production, as 
individual firms and countries focus on specific tasks within the production process rather than producing a whole product in one location. Some of these value chains have existed for many years (Elms \& Low 2013), such as the US automotive value chain and some textile value chains in Asia.

The 'splitting' of production into various tasks, therefore, causes high interdependence between firms involved in the production process, and they rely on each other for speed, predictability and flexibility (Kleynhans \& Drewes 2008a:3). This, in turn, creates the need for supportive government policies and regulations for the movement of both goods and people across borders, without too much intervention in the overall production process (Grater 2014).

Current approaches to GVCs are mostly derived from the original model suggested by Michael Porter (1985), and this has been developed further into the current view of global trade (Gurría 2012) as reported by the United Nations Conference on Trade and Development (UNCTAD, 2013) and the World Trade Organization (WTO).

Many of the core functions of firms are either established in different locations through FDI or outsourced to local firms in different destinations. Multinational firms now tend to invest in part of the production process in destinations that give them the greatest benefit, for the purpose of raising profits and selling locally, but also to distribute from these locations to the rest of the world. Therefore, the development of these GVCs and RVCs has changed the needs of investors. The investment packages they require are different and governments are required to adapt to their changing needs.

The benefits of this kind of investment are much greater than traditional FDI, where MNEs have gained most from investment in the long run. Foreign direct investment can also lead to positive spillover effects in terms of technology, skills and knowledge in the local economy of the host country. Therefore, investment that is driven by the unbundling of the production process has a greater impact on the local economy and can lead to long-term sustainable growth and development.

For the local economy to see the benefits of investment for value chain purposes, policies and regulations must be updated and shaped to allow for this change in the commercial landscape. White and Fan (2006) explain that, in the past, government policies were mostly protective in nature but at the same time promoted FDI. More recently, the focus has shifted and there is a greater need for governments to remove their protectionist policies in order to allow the free movement of goods, factors of production and knowledge. This is especially important for MNEs aiming to establish production processes in different countries.

\section{The role of agro-industrial value chains in Southern Africa}

Most Southern African countries are still strongly reliant on commodities and agricultural sectors, despite the declining demand for commodities (Coetzee et al. 2016). Coupled with this, the importance of FDI has grown for foreign landowners throughout Africa, especially with regard to the growing uncertainty in the African policy sphere. Efforts are underway to tighten regulations for foreign land ownership and agricultural activity in the region (Cotula 2009). However, not much research has been conducted relating to the dynamics of the agricultural sector in terms of the greater value chain in the region.

The agricultural value chain can be split into three types, namely primary food products, processed food products and processed (non-consumable) agricultural products (Van der Merwe et al. 2016:652).

Leading investment firms in agro-industry value chains are largely driven by commodities. Some may be buyer driven (such as for fresh fruit and vegetables), where other are supplier driven (such as for food and beverage manufacturing). Farole and Winkler (2014) highlight that much of the foreign investment within the African context has been in agricultural land and mostly in resource-poor countries aiming to secure food production elsewhere. There has also been a trend toward contract farming and outsourcing agricultural products rather than pure farming. This type of investment has higher spillover effects for the region.

Agro-processing value chains in the region have been dominated by South African firms (World Bank 2016b). There is a definite imbalance in the production capacity of various Southern African countries, and South Africa has been leading the way in terms of production (Bezuidenhout \& Kleynhans 2017:235; Grobbelaar \& Meyer 2017). Large South African retailers dominate the region's value chains and largely dictate the dynamics in this industry, including FDI in the sector.

South Africa is the largest supplier of outward agro-industrial FDI to the rest of Southern Africa, while its agro-industrial sector also receives most FDI from the rest of the world (FDI intelligence 2015). Where South Africa's FDI in agriculture originates and how it is linked to South Africa's own outward investment in agriculture in other Southern African countries does, however, need much more attention and research, providing a rationale for the current article.

The next sections aim firstly to evaluate the nature and dimensions of the different sub-sectors that receive investment in South Africa and secondly to investigate South African investment patterns into Africa.

\section{Investment trends in Africa}

The integration of Africa into global trade and global production networks has changed the traditional way of doing business in Africa (Kleynhans \& Naudé 2006). Longterm pressure has driven more transparency and best principle practices to be established in Africa. One of the 
major questions that will need to be addressed by African policymakers in the coming years is the ability of African firms to effectively integrate into GVCs, with the increased potential for long-term sustainable development and investment (Bongsha et al. 2014). This does not bode well for the traditional resource-extracting rent-seeking elites, as these trends are more open and have a wider distribution of benefits.

Investment in Africa has also seen some changes in recent years. During 2014, while FDI to Africa rose by $64 \%$, France was the main source of FDI investments to Africa, equalling $\$ 18.3$ billion (FDI intelligence 2015). Financial services have been a leading non-resources sector, attracting FDI into Africa since 2006. These figures correlate with a continual increase in the number of bank accounts, rising from $18 \%$ of the population in 2006 to 36\% in 2011 (World Bank 2017).

The UNCTAD (2015) indicated that Central Africa and Southern Africa expanded the most significantly; however, they declined in FDI during 2014-2015. The report attributed this trend to the end of the commodity 'super cycle', which directly impacted resource-seeking FDI into Africa.

According to Ernst \& Young's Investor Attractiveness Survey (2017), FDI projects decreased, but the specified amounts and numbers of jobs have increased. Southern Africa experienced a decrease of $11 \%$ in the number of projects. Traditional investors indicated that the decrease was caused by the 'higher risk' perception of African countries, which was caused by the large drop in the commodity cycle (Coetzee et al. 2016). Since 2007, the number of FDI projects in Africa grew at a rate of $10.8 \%$ per annum, of which Southern Africa received approximately one-third. There was, however, a decline of $11.4 \%$ in inward flows during 2014 and an increase of \$33bn in capital, which was more than double (Ernst \& Young 2017).

While Mozambique and Angola are expected to experience growth rates of more than 5\% between 2015 and 2020, Botswana, Namibia and South Africa are expected to grow only between $0 \%$ and $5 \%$ during the same period, although one should also consider that these three countries are starting from a higher economic base than the former three countries. This low growth forecast is also intertwined with structural economic problems in the region, as increases in growth have not translated into higher standards of living. According to the World Economic Forum (2015), most African countries still underperform in all competitiveness categories. This means that Africa is not regarded as an attractive investment destination, especially for multinational firms searching for value chains in cost-effective and competitive destinations.

South Africa has remained the leading investment destination in Southern Africa in 2014 (FDI Intelligence 2015). The next section investigates the investment inflows in South Africa, with a specific focus on the agricultural sector.

\section{Foreign direct investment inflows to South Africa}

South Africa received $18 \%$ of all FDI projects on the continent during 2013. UNCTAD (2015) found that FDI into South Africa fell in value by approximately $74 \%$ to $\$ 1.5$ billion in 2014. Ernst \& Young (2017) also refer to this decline by stating that 'there was a marked fall in FDI projects announced in South Africa in 2014'. While South Africa is the biggest economy in the region, it had experienced a decline of $17.7 \%$ since 2013 and had only attracted 121 projects. Where other countries saw an increase of capital amounts and increased jobs with fewer projects, the same did not occur in South Africa. South Africa's FDI inflows peaked in 2008, and it has been difficult to maintain these levels ever since. South Africa's FDI outflows also declined rapidly during the same period.

The main investors in South Africa were the United States, the United Kingdom, Australia, Germany and Italy (fDi Markets 2018). The dominant sectors receiving FDI were metal and coal, oil and natural gas, as well as alternative and renewable energy (Coetzee et al. 2016). Ernst \& Young (2015) also highlight the increasing technology investment, with approximately one-fifth of Africa's investment projects during 2014 being technology, media and telecoms. South Africa was the top destination for these investment projects. They also indicate that consumer and retail FDI into South Africa declined significantly.

In terms of M\&A, South Africa saw some changes in dynamics. The large mining corporation Anglo American, which was originally from South Africa but relocated to London, remains the largest corporate investor in South Africa (Bureau Van Dijk 2018). Sources such as BHP Billiton and Molopo Australia indicated that South Africa's FDI is mostly linked to strong historical ties.

ACWA Power International from Saudi Arabia, Statoil from Norway, Kruse from Germany and Tata from India are but a few companies that have top investors and they reflect the rich diversity of foreign investors in South Africa. From 2004 to 2014, South Africa received 4428 inward M\&A, of which most were from the United Kingdom, United States and Australian companies. The Bureau Van Dijk (2015) indicates that China, Russia and Canada have become significant source countries in terms of the value of deals.

The agricultural sector, in particular, experienced some important developments. Greenfield investments, specifically in agriculture, are shown in Figure 1. Greenfield FDI entails a new business venture that requires new operational facilities to be established (Coetzee et al 2016). It reveals the dominance of biomass power investment, followed distantly by breweries and distilleries, agricultural, construction and mining machinery. The visibility of Mahindra, Minsk Tractors and John Deere in the companies list indicates the importance 


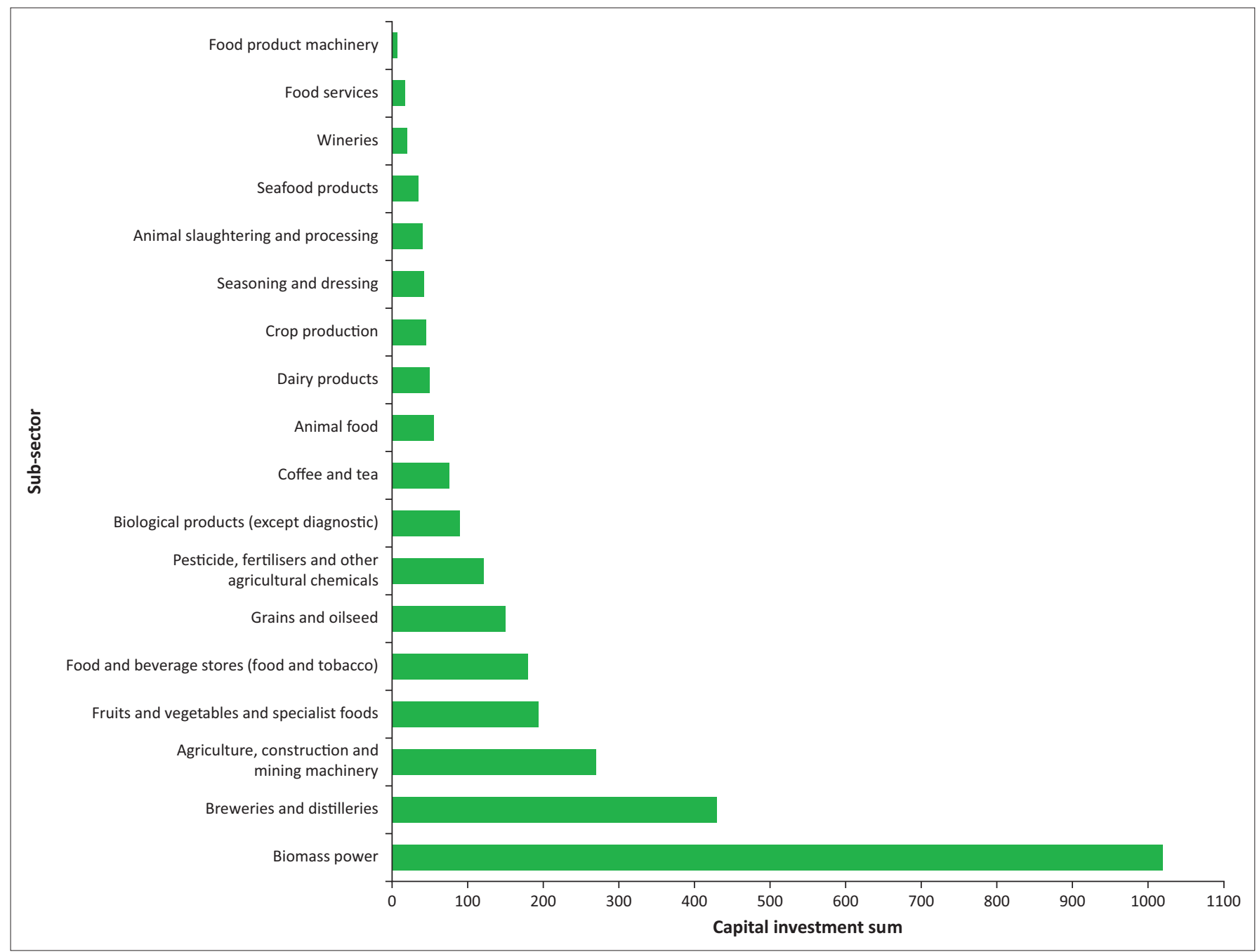

Source: Authors' analysis using fDi Markets (2018)

FIGURE 1: Total greenfield foreign direct investment inflows into South Africa by sub-sector, 2003-2014 (US\$, millions).

of agriculture in this sub-sector. The rest of the investments are dispersed between agricultural inputs and processing, such as fertiliser and farming sub-sectors.

In terms of the number of products, agriculture, construction and mining machinery received 21 projects between 2003 and 2014, followed by 10 projects in the food and beverage sub-sector. Therefore, the value of investment does not necessarily follow the number of projects invested in. Figures by fDi Markets (2018) indicated that the FDI in the various agriculture sub-sectors in the same period led to the creation of 13854 jobs, which is not many.

Table 1 indicates the FDI received by South Africa's agricultural sector from an industry activity perspective. The major trend is towards investment in manufacturing, which received 41 projects. This includes all types of agricultural machines for crop and livestock production. The number of jobs created in manufacturing is also far more than the other activities. This number of projects and employment created indicate that FDI in the agro-industry supports manufacturing and job creation, which is overall supportive of economic growth.
TABLE 1: Agricultural foreign direct investment inflows to South Africa by industry activity, 2003-2014.

\begin{tabular}{lccc}
\hline Industrial activity & $\begin{array}{c}\text { Capital investment } \\
\text { (US\$, millions) }\end{array}$ & $\begin{array}{c}\text { Jobs } \\
\text { created }\end{array}$ & $\begin{array}{c}\text { Number of } \\
\text { projects }\end{array}$ \\
\hline Manufacturing & 2047 & 10722 & 41 \\
Electricity & 425 & 94 & 2 \\
Sales, marketing and support & 384 & 236 & 13 \\
Logistics, distribution and transportation & 143 & 775 & 8 \\
Retail & 134 & 1431 & 9 \\
Design, development and testing & 52 & 229 & 5 \\
Headquarters & 28 & 133 & 3 \\
Business services & 21 & 53 & 4 \\
Education and training & 19 & 180 & 3 \\
Maintenance and servicing & 10 & 54 & 2 \\
\hline
\end{tabular}

Source: Authors' analysis using fDi Markets (2018)

Table 2 indicates the top 10 source countries for FDI in agriculture in South Africa between 2003 and 2014. The figures indicate the dominance of the United Kingdom and the Netherlands as the leading sources of FDI in agriculture to South Africa. The United States followed by Switzerland, Australia and Japan forms a second grouping based on the amount spent by the source countries; Austria and Germany form a third grouping, with Canada, India and China making up the last of the top 10 source countries. When the number of 
projects is considered, the United States and the United Kingdom dominate the landscape. South Africa depends on the European Union for investment in agriculture, followed by the anglicised world and growing interest from the dominant BRICS countries (the grouping of the world's leading emerging economies, namely Brazil, Russia, India, China and South Africa), with the emphasis on China and India.

Table 3 further illustrates the diverse number of companies that invest in agriculture in South Africa. Although the table covers only the top 19 companies, the pattern of a diversified and cross-industry investment is evident. Unilever and Cargill have been the only multi sub-sector investors, while the other firms tend to be highly focused in their investments.

The figures presented in Tables 1 and 2 indicate the highly diverse investment that South Africa receives for its agricultural sector. Most of the investment has, however, been in manufacturing and production in this sector.

TABLE 2: Agricultural foreign direct investment inflows to South Africa according to investor country, 2003-2014.

\begin{tabular}{lccc}
\hline Countries & $\begin{array}{c}\text { Capital investment } \\
\text { (US\$, millions) }\end{array}$ & Jobs created & $\begin{array}{c}\text { Number of } \\
\text { projects }\end{array}$ \\
\hline United Kingdom & 556 & 2042 & 12 \\
Netherlands & 545 & 856 & 9 \\
United States & 398 & 1632 & 16 \\
Switzerland & 322 & 3096 & 8 \\
Australia & 297 & 808 & 6 \\
Japan & 246 & 587 & 3 \\
Austria & 187 & 462 & 3 \\
Germany & 141 & 1574 & 3 \\
Canada & 106 & 535 & 2 \\
India & 102 & 613 & 3 \\
China & 91 & 367 & 5 \\
Italy & 70 & 328 & 2 \\
Botswana & 51 & 546 & 4 \\
\hline
\end{tabular}

Source: Authors' analysis using fDi Markets (2018)

TABLE 3: Major agricultural foreign direct investment inflows to South Africa by company, 2003-2014.

\begin{tabular}{llc}
\hline Investing company & Source country & $\begin{array}{c}\text { Capital investment } \\
\text { (US\$, millions) }\end{array}$ \\
\hline Heineken & Netherlands & 429 \\
Wasabi Energy & Australia & 219 \\
Cargill & United States & 218 \\
Lonza & Switzerland & 208 \\
Mitsui \& Co & Japan & 188 \\
Unilever & United Kingdom & 171 \\
Austrian Energy \& Environment & Austria & 156 \\
Helius Energy & United Kingdom & 156 \\
McCain Foods & Canada & 106 \\
Uhde & Germany & 94 \\
Ferrero & Italy & 70 \\
Bharat Biotech & India & 67 \\
Woolworths & Australia & 66 \\
SAB Maltings & United Kingdom & 65 \\
Illovo Sugar Ltd & United Kingdom & 55 \\
Choppies & Botswana & 51 \\
LignoTech & Norway & 45 \\
Spar & Netherlands & 41 \\
MAN Ferrostaal & Germany & 40 \\
\hline Source:Authors & &
\end{tabular}

Source: Authors' analysis using fDi Markets (2018)

\section{South Africa's foreign direct investment outflows into Africa}

South Africa has become a leading investor in Africa, with a $5 \%$ share in OFDI into Africa. This is led by financial services and telecommunications, where South African investment created 6964 jobs (FDI Intelligence 2015). Ernst \& Young (2015) also indicate similar investments in financial services, technology, media and telecommunications.

\section{South African greenfield investments in agriculture}

Since the financial crisis of 2008, there has been a marked increase in FDI outflows from South Africa in the agricultural sector. The drought of 2016 placed a further burden on the agricultural sector, which has led to more farmers and agricultural companies seeking to expand their operations to the rest of Africa. Table 4 shows the breakdown of FDI outflows by sub-sector from South Africa in agriculture. These figures indicate the highly diverse investment that South Africa enjoyed in its agricultural sector.

South Africa's outward investment flows in agriculture are dominated by the food and beverage sub-sectors, led by the Shoprite expansion into Africa, followed by breweries and wineries, sugar and agricultural equipment as the leading sectors. The figures indicate that South Africa's outward investment into Africa in agriculture leans much more towards support for agriculture than direct crop and animal production. This might be because it is difficult to secure actual production in Africa, and it may also be an indication of value chain growth, which is laying down agricultural infrastructure for the future production of crops and animals.

TABLE 4: Agricultural foreign direct investment outflows from South Africa by sector and sub-sector, 2003-2014.

\begin{tabular}{lccc}
\hline Industry/sub-sector & $\begin{array}{c}\text { Capital investment } \\
\text { (US\$, millions) }\end{array}$ & Projects & $\begin{array}{c}\text { Jobs } \\
\text { created }\end{array}$ \\
\hline Beverages & 232.9 & 3 & 666 \\
Breweries and distilleries & 113.9 & 5 & 339 \\
Wineries & & & \\
Business services & 8.4 & 1 & 31 \\
Environmental consulting services & & & \\
Chemicals & 4.7 & 1 & 18 \\
$\begin{array}{l}\text { Pesticide, fertilisers and other } \\
\text { agricultural chemicals }\end{array}$ & & & \\
Food and tobacco & 9.04 & 1 & 40 \\
Animal feed & 116.1 & 3 & 868 \\
Animal production & 69.5 & 1 & 450 \\
Animal slaughtering and processing & 169.8 & 3 & 1287 \\
Dairy products & 500.8 & 27 & 4797 \\
$\begin{array}{l}\text { Food and beverage stores } \\
\text { (food and tobacco) }\end{array}$ & & & \\
Food services & 90.1 & 4 & 1293 \\
Fruits and vegetables and specialist foods & 59.2 & 4 & 392 \\
Grains and oilseed & 6.2 & 1 & 60 \\
Sugar and confectionary products & 341.4 & 5 & 2012 \\
Industrial machinery, equipment and tools & & & \\
$\begin{array}{l}\text { Agriculture, construction and mining } \\
\text { machinery }\end{array}$ & 82.9 & 5 & 681 \\
Textiles & & & \\
Leather and hide tanning and finishing & 5.0 & 1 & 500 \\
\hline Source Auth' & & & \\
\hline
\end{tabular}

Source: Authors' analysis from fDi Markets (2018) 
Aggregated agricultural FDI outflow data are provided in Table 5, which confirms that manufacturing in agriculture dominates FDI outflows from South Africa.

Specific data from fDi Markets (2018) shows the breakdown of South Africa's agriculture FDI outflows by destination country, indicated in Table 6. Of the top FDI destinations for South African agricultural FDI, only three are non-African countries. Investment in Mozambique, Angola and Nigeria is most prominent, which is significant as Mozambique and Angola have vast untapped agricultural potential themselves. Nigeria is one of the largest agricultural producers in Africa, even though it does not generally produce enough for its own population.

South African companies investing in African agriculture are dominated by Shoprite and Pick n Pay, with a combined

TABLE 5: Agricultural foreign direct investment outflows to South Africa by industry activity, 2003-2014.

\begin{tabular}{lccc}
\hline Industry activity & $\begin{array}{c}\text { Capital investment } \\
\text { (US\$̦, millions) }\end{array}$ & $\begin{array}{c}\text { Jobs } \\
\text { created }\end{array}$ & Projects \\
\hline Manufacturing & 1087.9 & 6926 & 22 \\
Retail & 551 & 5796 & 29 \\
Logistics, distribution and transportation & 102.4 & 483 & 5 \\
Sales, marketing and support & 60.2 & 198 & 8 \\
Business services & 8.4 & 31 & 1 \\
\hline
\end{tabular}

Source: Authors' analysis from fDi Markets (2018)

TABLE 6: Major destinations for agricultural foreign direct investment outflows from South Africa, 2003-2014.

\begin{tabular}{lccc}
\hline Country & $\begin{array}{c}\text { Capital investment } \\
\text { (US\$, millions) }\end{array}$ & Jobs created & $\begin{array}{c}\text { Number of } \\
\text { projects }\end{array}$ \\
\hline Mozambique & 346.0 & 2395 & 6 \\
Nigeria & 320.5 & 1883 & 9 \\
Angola & 210.3 & 1606 & 8 \\
Sri Lanka & 110.0 & 400 & 1 \\
Zambia & 108.2 & 861 & 5 \\
India & 98.6 & 909 & 4 \\
Congo (DRC) & 96.6 & 577 & 2 \\
Namibia & 80.0 & 494 & 3 \\
Ghana & 67.3 & 576 & 3 \\
Hong Kong & 54.1 & 114 & 2 \\
Republic of the Congo & 48.2 & 401 & 1 \\
\hline
\end{tabular}

Source: Authors' analysis from fDi Markets (2018)

TABLE 7: Agricultural foreign direct investment outflows from South Africa by company, 2003-2014.

\begin{tabular}{lccc}
\hline Companies & $\begin{array}{c}\text { Capital investment } \\
\text { (US\$, millions) }\end{array}$ & $\begin{array}{c}\text { Jobs } \\
\text { created }\end{array}$ & Projects \\
\hline Remgro & 401.3 & 1495 & 5 \\
Shoprite & 368 & 3480 & 18 \\
Tongaat Hulett & 223.95 & 1394 & 3 \\
Clover Industries & 169.8 & 1287 & 3 \\
Pick n Pay & 132.77 & 1317 & 9 \\
NMI Group & 78.57 & 490 & 2 \\
Nando's & 55.8 & 1086 & 3 \\
Astral Foods & 55.7 & 429 & 1 \\
Africom Commodities & 48.2 & 401 & 1 \\
Christo Wiese Portfolio & 39.3 & 199 & 1 \\
Bright World & 35.1 & 92 & 1 \\
Vida e Caffè & 34.3 & 207 & 1 \\
HL Hall \& Sons & 26.8 & 101 & 2 \\
Fry's Vegetarian (Fry Group Foods) & 25.7 & 255 & 1 \\
VR Steel & 24.7 & 188 & 1 \\
\hline
\end{tabular}

Source: Authors' analysis from fDi Markets (2018)
27 projects (FDI Intelligence 2017). Remgro has been the largest investor in terms of actual capital investment, as illustrated in Table 7.

In summary, agricultural FDI outflow from South Africa is not as diverse as inflows, yet it is moderately diverse for a developing country. Expansion seems highly focused on the African region, with the majority of investment being in agricultural retail and manufacturing. These investment trends could form the foundation for future agriculture value chains in Africa, with specific expansion occurring in production and support infrastructure. It can be inferred that South African firms regard Africa as the dominant expansion space for future market development. The next section investigates M\&A of South African agriculture and agro-industries.

\section{South African mergers and acquisitions in agriculture}

The M\&A data for South Africa also indicates remarkable trends. The review of M\&A flows is based on Standard Industrial Classification codes and is specific for agricultural products. This offers some products that might seem out of place, but they do fall under the sub-sector of agriculture.

Table 8 highlights the largest agricultural M\&A between South Africa and other countries, sorted by industrial activity. Most M\&As shown in Table 8 are fewer than two deals. The largest investments relate to alcoholic beverage production. Most of the investments are in the manufacturing sector using agricultural products as inputs. This diverse portfolio highlights the difficulty of investment in the agricultural sector by foreign MNEs.

TABLE 8: Agricultural mergers and acquisitions inflows into South Africa by industry activity, 2003-2014.

\begin{tabular}{lcc}
\hline $\begin{array}{l}\text { Target primary Standard Industrial } \\
\text { Classification description }\end{array}$ & $\begin{array}{c}\text { Deal value } \\
\text { (US\$, millions) }\end{array}$ & $\begin{array}{c}\text { Number } \\
\text { of deals }\end{array}$ \\
\hline Business services, not elsewhere classified & 659.37 & 1 \\
Cane sugar refining & 522.05 & 1 \\
Cigarettes & 234.74 & 1 \\
Malt beverages & 214.20 & 3 \\
\hline Fluid milk & 124.23 & 1 \\
Cement, hydraulic & 112.25 & 1 \\
Flour and other grain mill products & 97.34 & 2 \\
Wines, brandy and brandy spirits & 57.89 & 6 \\
Cotton ginning & 37.82 & 1 \\
Grapes & 35.43 & 4 \\
Tour operators & 25.76 & 1 \\
Leather tanning and finishing & 22.35 & 1 \\
Distilled and blended liquors & 17.75 & 2 \\
\hline Animal and marine fats and oils & 16.53 & 1 \\
\hline Dimension stone & 16.32 & 2 \\
\hline Building cleaning and maintenance services, & 14.50 & 1 \\
not elsewhere classified & & 2 \\
Sugarcane and sugar beets & 14.12 & 2 \\
Poultry hatcheries & 12.61 & 2 \\
Natural, processed and imitation cheese & 12.53 & 1 \\
\hline Lawn and garden services & 6.13 & 2 \\
\hline Source: Authos' analyis from Burau & \\
\hline
\end{tabular}

Source: Authors' analysis from Bureau Van Dijk, Zephyr database (2018) 
Comparing industry and country investments, most investments are in production and support and thus manufacturing. This shows that foreign companies are in general not interested in buying South African crops and livestock, and when they do the focus is on agro-industries.

Similar to greenfield investments, the most important countries involved in M\&As are the United Kingdom, the United States and the Netherlands. France is also part of the list and most of the investments are by developed countries, except for the one project by Dangote of Nigeria (see Tables 9 and 10). Dangote is the largest African company outside South Africa.

With such a wide array of single deals, it is almost impossible to list the companies involved. Table 10 shows the top investors in South Africa in terms of M\&As from 2003 to 2014. Beverage manufacturer SAB Miller, previously from South Africa and now based in the United Kingdom, is the leading investor. A total of 70 companies invested and most have had only one or two deals.

South Africa's agricultural M\&A outflow data show similar patterns, although much less in terms of value and number of deals. South Africa's outward M\&As in agriculture are also widely diverse, with single deals per sector being the norm, as illustrated in Table 11. Alcoholic beverages are an exception.

The target destination countries for M\&As from South Africa in agriculture also follow a similar pattern to greenfield investments. Table 12 provides a breakdown by country from 2003 to 2014

TABLE 9: Agricultural mergers and acquisitions inflows into South Africa by source country, 2003-2014.

\begin{tabular}{lcc}
\hline Acquirer country & $\begin{array}{c}\text { Deal value } \\
\text { (US\$̦, millions) }\end{array}$ & $\begin{array}{c}\text { Number } \\
\text { of deals }\end{array}$ \\
\hline United Kingdom & 1256.63 & 15 \\
United States & 307.11 & 16 \\
Netherlands & 178.20 & 7 \\
France & 126.16 & 8 \\
Nigeria & 112.25 & 1 \\
Virgin Islands (British) & 97.34 & 1 \\
Luxembourg & 66.01 & 3 \\
Germany & 25.76 & 4 \\
Canada & 22.35 & 3 \\
Hong Kong & 20.00 & 1 \\
\hline
\end{tabular}

Source: Authors' analysis from Bureau Van Dijk, Zephyr database (2018)

TABLE 10: Agricultural mergers and acquisitions inflows into South Africa by company, 2003-2014.

\begin{tabular}{lcc}
\hline Acquirer name & $\begin{array}{c}\text { Deal value } \\
\text { (US\$̦, millions) }\end{array}$ & $\begin{array}{c}\text { Number } \\
\text { of deals }\end{array}$ \\
\hline SABMiller Plc & 659.37 & 1 \\
ABF Overseas Ltd & 522.05 & 1 \\
Philip Morris International Inc. & 234.74 & 1 \\
Heineken NV & 173.25 & 2 \\
Danone SA & 124.23 & 1 \\
Dangote Industries Ltd & 112.25 & 1 \\
Capital Partners Group Holdings Ltd & 97.34 & 1 \\
Citation Holdings SA & 51.89 & 1 \\
Cargill Inc. & 37.82 & 1 \\
Diageo Plc & 36.00 & 2 \\
\hline
\end{tabular}

Source: Authors' analysis from Bureau Van Dijk, Zephyr database (2018)
Two important phenomena can be derived from Table 12 . Firstly, the developed world focuses more on manufacturing and securing markets for their products. The second is the focus of the developing world on support and manufacturing. That begs the question as to whether investments increase exports, are linked to exports or are solely intended for the local market.

Considering outflows from South Africa resulting from M\&As of South African companies, 37 companies from South Africa invested abroad through the M\&A process, with most having one or two deals (see Table 13). The Distell Group is the exception.

South African M\&As have a much smaller scope than greenfield investments; however, it is just as widely dispersed among sectors. The largest investors are the United Kingdom, the United States, the Netherlands and France. South Africa

TABLE 11: Agricultural mergers and acquisitions outflows from South Africa by industry activity, 2003-2014.

\begin{tabular}{|c|c|c|}
\hline $\begin{array}{l}\text { Target primary United States Standard } \\
\text { Industrial Classification description }\end{array}$ & $\begin{array}{l}\text { Deal value } \\
\text { (US\$, millions) }\end{array}$ & $\begin{array}{l}\text { Number } \\
\text { of deals }\end{array}$ \\
\hline Distilled and blended liquors & 381.4 & 6 \\
\hline Cement, hydraulic & 287.5 & 1 \\
\hline Cigarettes & 238.3 & 1 \\
\hline Flour and other grain mill products & 191.5 & 1 \\
\hline Cane sugar refining & 165.1 & 3 \\
\hline $\begin{array}{l}\text { Offices of holding companies, not elsewhere } \\
\text { classified }\end{array}$ & 92.4 & 2 \\
\hline Glass containers & 58.8 & 1 \\
\hline Management consulting services & 21.7 & 1 \\
\hline Fresh fruits and vegetables, wholesale dealing & 17.3 & 2 \\
\hline $\begin{array}{l}\text { Bread and other bakery products, except cookies } \\
\text { and crackers }\end{array}$ & 10.9 & 1 \\
\hline Broad woven fabric mills, cotton & 10.3 & 1 \\
\hline Wines, brandy and brandy spirits & 9.7 & 3 \\
\hline Malt beverages & 6.9 & 1 \\
\hline $\begin{array}{l}\text { Electronic parts and equipment, not elsewhere } \\
\text { classified, wholesale dealing }\end{array}$ & 6.0 & 1 \\
\hline Dairy farms & 6.0 & 1 \\
\hline Meat packing plants & 5.1 & 1 \\
\hline Ornamental floriculture and nursery products & 5.0 & 1 \\
\hline Phosphoric fertilisers & 4.4 & 2 \\
\hline Animal aquaculture & 3.5 & 1 \\
\hline $\begin{array}{l}\text { Industrial machinery and equipment, wholesale } \\
\text { dealing }\end{array}$ & 3.4 & 1 \\
\hline
\end{tabular}

Source: Authors' analysis from Bureau Van Dijk, Zephyr database (2018)

TABLE 12: Agricultural mergers and acquisitions outflows from South Africa by source country, 2003-2014.

\begin{tabular}{lcc}
\hline Target country & Deal value (US\$, millions) & Number of deals \\
\hline United Kingdom & 619.36 & 8 \\
Nigeria & 478.95 & 6 \\
Mali & 165.07 & 1 \\
Kenya & 73.49 & 3 \\
France & 39.33 & 2 \\
Zimbabwe & 16.3 & 4 \\
Swaziland & 10.93 & 3 \\
Romania & 6.9 & 1 \\
Australia & 6.51 & 2 \\
Tanzania & 5.09 & 1 \\
India & 4.38 & 2 \\
Chile & 3.5 & 1 \\
\hline
\end{tabular}

Source: Authors' analysis from Bureau Van Dijk, Zephyr database (2018) 
mainly invests in Africa. Investments in the developed world are to obtain a wider market share, while investments in the developing world are in inputs and manufacturing.

TABLE 13: Agricultural mergers and acquisitions outflows from South Africa by company, 2003-2014.

\begin{tabular}{lcc}
\hline Acquirer name & $\begin{array}{c}\text { Deal value } \\
\text { (US\$, millions) }\end{array}$ & $\begin{array}{c}\text { Number } \\
\text { of deals }\end{array}$ \\
\hline Distell Group Ltd & 294.64 & 6 \\
Public Investment Corporation Ltd & 287.49 & 1 \\
Remgro Ltd & 238.27 & 1 \\
Tiger Brands Ltd & 191.46 & 3 \\
Illovo Sugar Ltd & 165.07 & 2 \\
Mr Vivian Imerman & 96.44 & 2 \\
Rainbow Chicken Ltd & 92.42 & 1 \\
Consol Glass (Pty) Ltd & 58.77 & 1 \\
Murray \& Roberts Holdings Ltd & 21.74 & 1 \\
Capespan Group Holdings Ltd & 17.31 & 1 \\
Agri-Vie Investment Advisors (Pty) Ltd & 13.44 & 3 \\
Premier Foods (Pty) Ltd & 10.93 & 1 \\
\hline Source: &
\end{tabular}

Source: Authors' analysis from Bureau Van Dijk, Zephyr database (2018)
The information provided so far in this section indicates that there is potential for development of agricultural value chains in Africa. Currently, South Africa is the lead investor both in terms of greenfield opportunities and M\&As, but how South Africa's FDI inflows in agriculture link to its outflows, and whether South Africa can be viewed as the core of a larger value chain, should be further researched.

The World Bank (2016b) views the regional agro-processing industry as imbalanced, with South Africa significantly dominating production. The figures show that South Africa also dominates investment in agriculture. The large South African retailers dominate regional supply chains and largely dictate the dynamics in the industry. The World Bank report also highlights the need for a longer-term strategy in the Southern African region in order to drive further development in agricultural value chains. The need for better infrastructure and the removal of supply chain inefficiencies is highlighted.

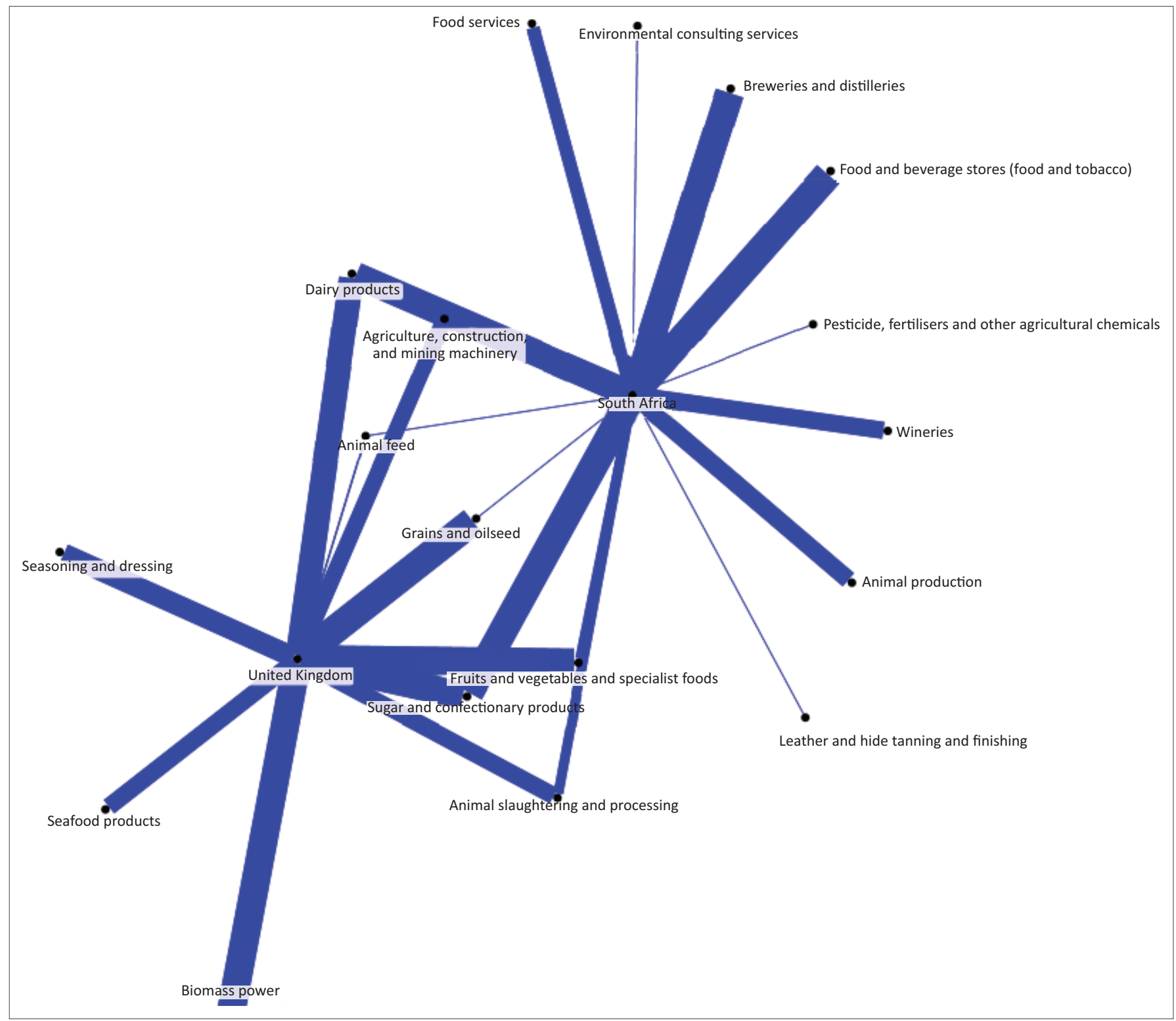

Source: Authors' analysis from fDi Markets (2018)

FIGURE 2: Foreign direct investment linkages in agriculture between the United Kingdom and South Africa versus South Africa and Africa. 
Agricultural value chains are quite complex and may even influence the type of FDI inflows, as well as possible FDI spillovers (Farole \& Winkler 2014).

The next section aims to review potential linkages in FDI patterns in agriculture, both from inward FDI received in South Africa and South Africa's outward FDI. The aim is to determine whether the agricultural value chains in the region are also driven by larger value chains than just regionally. The dynamics of such a value chain will be very different to one only driven by South African MNEs.

\section{Link between South Africa's foreign direct investment inflows and outflows in agriculture}

South African firms dominate agricultural FDI inflows in Africa, where investors from developed nations dominate the agricultural investment landscape in South Africa (Ernst \& Young 2015).

The linkages between inward and outward FDI are displayed and analysed with the use of 'spider graphs'. This is the best way to link the two forms of FDI flows in specific sectors. These graphs illustrate the volume of geographical linkages and products through the width of the lines, enabling easy comparison. Three source countries were selected because of their large investments in the South African market, namely the United Kingdom, the United States and the Netherlands. Figures 2-4 show the sectoral relationships between the investments from these partners into South Africa versus the sectoral investments of South African investors in Africa.

Figure 2 shows the patterns of investment from the United Kingdom in dairy products. Grains and oilseeds, fruits and vegetables, as well as sugar and confectionary products, are the dominant sectors in which South Africa also invests in Africa. It shows FDI inflows from the United Kingdom to South Africa and outflows from South Africa to the rest of Africa. Where the United Kingdom and South African lines meet, it indicates that the various flows coincide, implying the existence of a GVC. The thickness of the lines indicates the size of the flows and may therefore be an indication of international competitiveness in that specific sector.

Agriculture, construction and mining machinery, animal slaughtering and processing, as well as animal feed, are important sectors in this instance (Figure 2). The strong linkages of the grains and oilseed, fruits and vegetables, dairy products, and sugar and confectionary sectors indicate either that South African firms are in a position where they have access to new technology and human capital-related technologies that provide new opportunities in Africa or that they are being crowded out of their local market and forced to seek new opportunities elsewhere in Africa. Unlike the United States and the Netherlands, investment from the United Kingdom does not form a significant pattern of this value chain investment.
Figure 3 shows the patterns of investment from the United States, which marks a definitive departure from those of the United Kingdom. There are several sectoral links; however, only agriculture, construction and mining machinery, food and beverage investments, as well as grain and oilseeds, show strong linkages. These major sectors are also inputs or post-agricultural production sectors that represent value chain investments. The number of linkages that are not as strong as in the United Kingdom suggests that the onward investment from South African firms to Africa will be caused by spillovers and resulting increases in competitive advantage, rather than a crowding-out effect. This establishes the value chain argument of this paper.

The pattern of investment from the Netherlands only exists in three sectors, of which two have a very strong connection, according to Figure 4 . Food and beverage investments, as well as breweries and distilleries, indicate increasing levels in competition with South Africa that forces the South African firms to seek new opportunities to remain competitive.

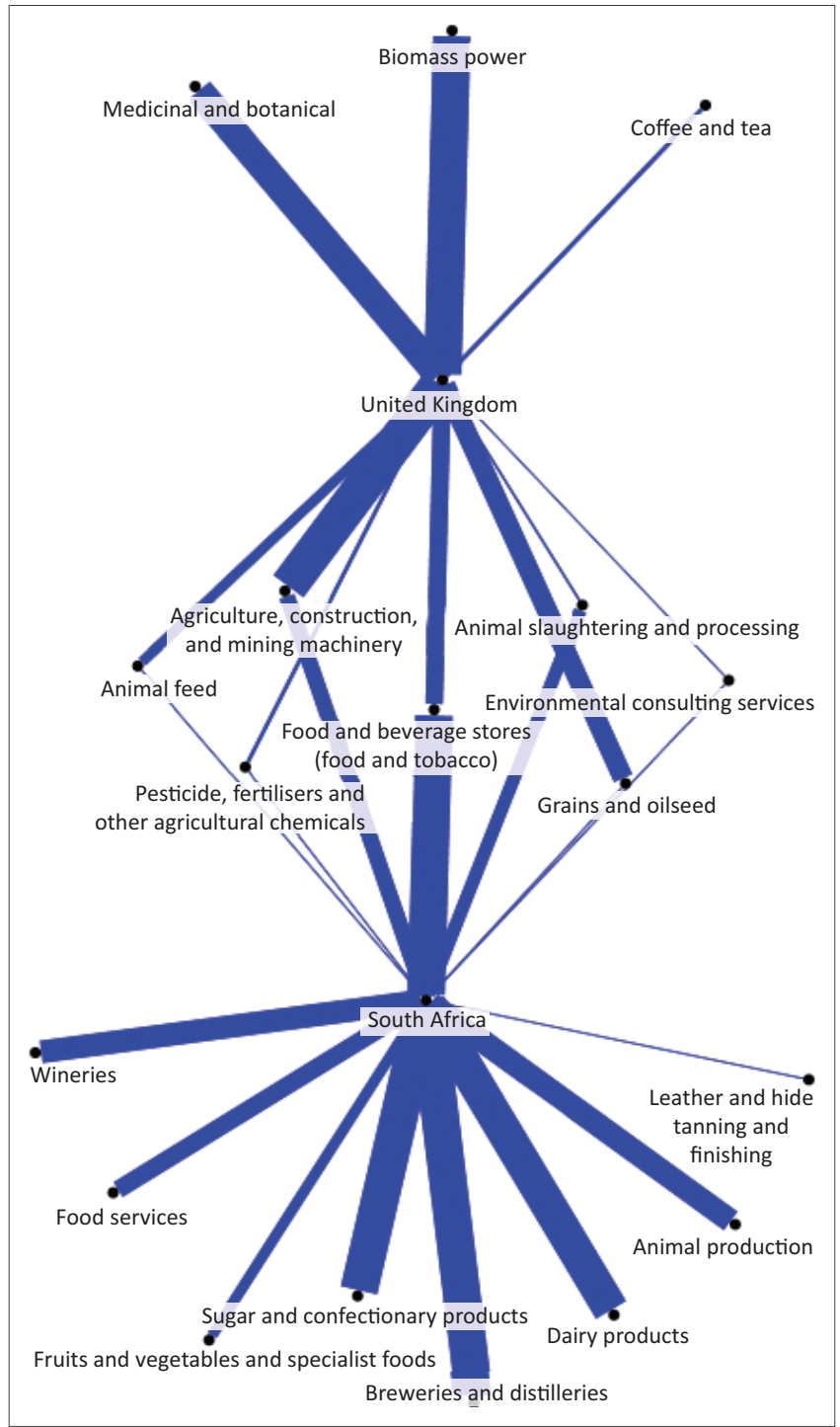

Source: Authors' analysis from fDi Markets (2018)

FIGURE 3: Foreign direct investment linkages in agriculture between the United States and South Africa versus South Africa and Africa. 
These sectors are also in production and retail, which form value-added sectors, indicating value chain investments. Pesticides, fertilisers and other agricultural chemicals show a low level of investment from the Netherlands to South Africa, with a stronger outward investment from South Africa. This suggests that spillovers and gains in competitive advantage lead to new possibilities in Africa. This is also an input-oriented investment that strengthens the value chain argument.

\section{Summary and conclusions}

This study investigated the flow of investment funds between South Africa, other African countries, and donor countries and companies abroad. African countries receive direct foreign funds (FDI), but investment funds also flow outward in the form of FDIs from South Africa. With the development of modern production and communication technologies, investments no longer only entail an increase of capital goods but are also a strategic decision that necessitates much information and planning. The production process can be divided and each section developed at the location of highest expertise and lowest costs, enhancing profits, wealth and the creation of employment opportunities. In Africa, with its high poverty levels and high unemployment rates, this is important.

The integration of Africa into the global trade and production networks, especially in the agro-industrial sector, is changing the traditional way of doing business in Africa. Long-term pressures are inclined towards more transparency and best principle practices. The integration into GVCs and sustainable investment options are major issues that have been addressed by African policymakers. The current research contributes insights in this regard.

This study evaluates the nature and dimensions of the different sub-sectors that receive investment in South Africa, as well as investigating the pattern of investment from South Africa

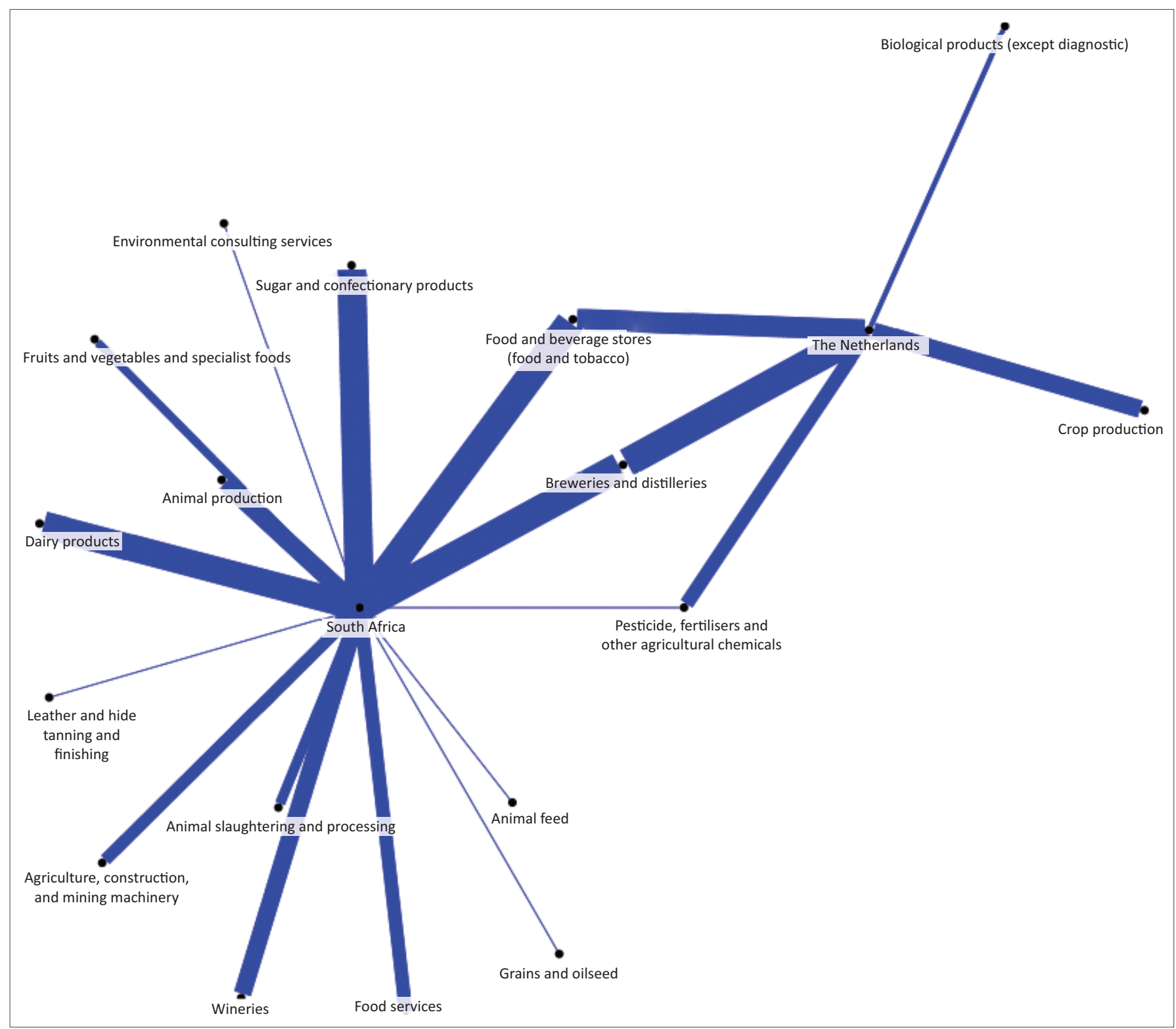

Source: Authors' analysis from fDi Markets (2018)

FIGURE 4: Foreign direct investment linkages in agriculture between the Netherlands and South Africa versus South Africa and Africa. 
into Africa. Total FDI into Africa increased by $64 \%$ during 2014. Foreign direct investment is centre to foreign landowners throughout Africa, especially in the wake of growing uncertainty in the policy sphere, particularly in countries such as the Congo, Zimbabwe and South Africa. South Africa and its companies are the leading recipients of FDI in the agroindustrial sector on the continent, but are also one of the largest suppliers of FDI to the rest of the African continent.

The type and size of risk to investments also differ between various sectors and regions and these specific risks to FDI need more attention. This study revealed that the motivation for cross-border investments, the dynamics of spillovers, and externalities still need to be researched further.

The study used qualitative data and visual techniques to disambiguate the linkages in FDI patterns with regard to regions, industries and specific companies. The results indicate that there are both local market investment and value chain investments on the continent.

The United States, the United Kingdom and the Netherlands are the largest investors in South Africa, with a strong focus on agricultural input production and subsequent agroprocessing industries. South African investment into Africa, in turn, follows a similar, albeit narrower and more focused, pattern. The study concludes that foreign MNEs are actively involved in GVC expansion, and South African firms are following suit. The lack of FDI in actual agricultural crop production offers future opportunities for higher investment flows and future development.

Investment flows from the United Kingdom to South Africa are not clearly defined. Many linkages from the United States exist and there are strong inputs to post-crop production and agroindustries, while many investments flow from the Netherlands as inputs and post-production in agro-industries. The United States and the Netherlands both offer high levels of competition and spillovers, leading to gains in efficiency, rendering South African firms more competitive on the continent. Exploring new markets and employing new technology resulting from capital formations through investments lead to new opportunities on the African continent. Studying the value chains and investment flows is important and yields important, detailed information, which is of particular importance to investors and the designers of policies.

\section{Acknowledgements}

The authors acknowledge the support from the World Trade Organization and the National Research Foundation. Opinions expressed and conclusions arrived at in the article are those of the authors and should not necessarily be attributed to these institutions.

\section{Competing interests}

The authors declare no conflict of interest with regard to the writing of this article.

\section{Authors' contributions}

H.B. designed the original concept and performed most of the original empirical analysis concerning the trade and FDI flows between regions and countries. S.G. conducted most of the theoretical and literature study and performed the empirical analysis on global value chains. E.P.J.K. assisted in the composition and evaluation and wrote the final article.

\section{References}

Allard, C., Chen, W. \& Kitsios, E., 2015, 'Trade integration and global value chains in sub-Saharan Africa: In pursuit of the missing link', in International Monetary Fund (ed.), Regional economic outlook for sub-Saharan Africa 2015, IMF, Washington, DC, $232 \mathrm{p}$.

Arestis, P., 1996, 'Post-Keynesian economics: Towards coherence', Cambridge Journal of Economics 20(1), 111-135. https://doi.org/10.1093/oxfordjournals.cje.a013604

Bezuidenhout, H. \& Grater, S., 2016, 'The dimensions of FDI in the tourism sector in Africa', Journal of Applied Business Research 32(4), 1115-1136. https://doi. org/10.19030/jabr.v32i4.9724

Bezuidenhout, H. \& Kleynhans, E.P.J., 2017, 'Chinese foreign direct investment in Africa: Something old, something new', Managing Global Transitions 14(3), 235-242.

Blonigen, B.A., 2005, 'A review of the empirical literature on FDI determinants', Atlantic Economic Journal 33(4), 383-403. https://doi.org/10.1007/s11293-0052868-9

Bongsha, B., Bezuidenhout, H., Kleynhans, E.P.J. \& Krugell, W.F., 2014, 'The effect of trade liberalisation on Cameroonian manufacturing export performance', Studia Oeconomica 59(1), 3-24.

Bureau Van Dijk, 2018, Zephyr database, viewed 30 April 2018, from https://zephyr. bvdinfo.com/

Coetzee, C.E. \& Kleynhans, E.P.J., 2018. 'Analysing industrial growth in various cities of KwaZulu-Natal province, South Africa', Journal of Economic and Financial Sciences. 11(1), a184, 1-12.

Coetzee, Z., Bezuidenhout, H., Claassen, C. \& Kleynhans, E.P.J., 2016, 'Profiling sectoral risks of foreign direct investment (FDI) in Africa for the first decade of the 21st century', Journal of Economic and Financial Sciences 9(1), 153-173. https://doi. century', Journal of Econor
org/10.4102/jef.v9i1.35

Cotula, L., 2009, Land grab or development opportunity?: Agricultural investment and international land deals in Africa, IIED, London.

Department of Mineral Resources (DMR), 2011, Beneficiation economics, viewed 30 April 2018, from http://www.dmr.gov.za/beneficiation-economics.html

Dunning, J.H., 2000, 'The eclectic paradigm as an envelope for economic and business theories of MNE activity', International Business Review 9(2), 163-190. https:// doi.org/10.1016/S0969-5931(99)00035-9

Dunning, J.H., 2001, 'The eclectic (OLI) paradigm of international production: Past, present and future', International Journal of the Economics of Business 8(2), 173190. https://doi.org/10.1080/13571510110051441

Dunning, J.H. \& Lundan, S.M., 2008, Multinational enterprises and the global economy, 2nd edn., Edward Elgar, Cheltanham.

Elms, D.K. \& Low, P., 2013, Global value chains in a changing world, WTO, WTO Publication, Geneva, viewed 30 April 2018, from https://www.wto.org/english/ res_e/booksp_e/aid4tradeglobalvalue13_e.pdf

Ernst \& Young, 2015, Africa attractiveness survey 2015, viewed 30 April 2018, from http://www.ey.com/Publication/vwLUAssets/EY-africa-attractiveness-survey-2015making-choices/\$FILE/EY-africa-attractiveness-survey-2015-making-choices.pdf

Ernst \& Young, 2017, EY's attractiveness program Africa, connectivity redefined, EY, Centurion.

Farole, T. \& Winkler, D. (eds.), 2014, Making foreign direct investment work for subSaharan Africa: Local spillovers and competitiveness in global value chains, Directions in Development, World Bank, Washington, DC.

FDI Intelligence, 2015, Africa investment report, FDI Intelligence, London, viewed 30 April 2018, from http://forms.fdiintelligence.com/report2015/

fDi Markets, 2018, Cross border investment monitor, fDi Markets, London, viewed 30 April 2018, from http://www.fdimarkets.com/

Grater, S., 2014, 'Comparative advantage of value-added services: The case of South Africa', Managing Global Transitions 12(3), 279-295.

Grobbelaar, S.S. \& Meyer, I.A., 2017, 'The dynamics of regional economic integration: A system dynamics analysis of pathways to the development of value chains in the Southern African Customs Union', South African Journal of Industrial Engineering 28(1), 73-89. https://doi.org/10.7166/28-1-1613

Gurría, A., 2012, The emergence of global value chains: What do they mean for business, G20 Trade and Investment Promotion Summit, OECD, Mexico City.

James, S., 2013, Tax and non-tax incentives and investments: Evidence and policy implications, World Bank Investment Climate Advisory Services, Washington, DC.

Kleynhans, E.P.J., 2016, 'Determinates of industrial competitiveness and the role of spillovers', Journal of Applied Business Research 32(2), 527-540. https://doi. org/10.19030/jabr.v32i2.9594 
Kleynhans, E.P.J. \& Drewes, J.E., 2008a, 'The influence of location on the efficiency of manufacturers in South Africa', Journal Town and Regional Planning 53, 1-8.

Kleynhans, E.P.J. \& Drewes, J.E., 2008b, 'The influence of location on the international competitiveness of South African industries', Journal of Economic and Financial Sciences 2(2), 139-158.

Kleynhans, E.P.J. \& Naudé, W.A., 2006, 'Suid-Afrikaanse nywerheidsontwikkeling te midde van globalisasie en moderne tegnologie', Tydskrif vir Geesteswetenskappe 46(3), 367-380.

Mallampally, P. \& Sauvant, K.P., 1999, 'Foreign direct investment in developing countries', Finance and Development 36(1), 34.

Moosa, I., 2002, Foreign direct investment: Theory, evidence and practice, Palgrave, Houndsmill, Basingstoke.

Porter, M.E., 1985, Competitive advantage: Creating and sustaining superior performance, Simon \& Schuster, New York.

Porter, M.E., 1998, The competitive advantage of nations; with a new introduction, Palgrave, New York.

Timmer, M.P., Erumban, A.A., Los, B., Stehrer, R. \& De Vries, G.J., 2014, 'Slicing up global value chains', Journal of Economic Perspectives 28(2), 99-118. https://doi. org/10.1257/jep.28.2.99

UNCTAD, 2013, World investment report 2013: Global value chains: Investment and trade for development, United Nations, New York.
UNCTAD, 2015, World investment report 2015: Reforming international investment governance, United Nations, New York.

Van der Merwe, J.D., Cloete, P.C., Van Schalkwyk, H.D. \& Kleynhans, E.P.J., 2016, 'The competitive status of the South African wheat industry', Journal of Economic and Financial Sciences 9(3), 651-665. https://doi.org/10.4102/jef.v9i3.63

White, C. \& Fan, M., 2006, Risk and foreign direct investment, Palgrave, Houndsmill, Basingstoke.

World Bank, 2016a, Factory Southern Africa? SACU in global value chains. Summary Report, World Bank, Washington, DC, viewed 30 April 2018, from http://www. saiia.org.za/value-chains-in-southern-africa/factory-southern-africa-sacu-inglobal-value-chains

World Bank, 2016b, Mapping global and regional value chains in SACU: Sector-level overviews, World Bank, Washington, DC, viewed 30 April 2018, from http:// documents.worldbank.org/curated/en/402161467996756902/Mapping-globaland-regional-value-chains-in-SACU-sector-level-overviews;jsessionid=v2c1IXFU$\mathrm{pY}+\mathrm{iVy}+7-0 \mathrm{WQuH} 5$

World Bank, 2017, World development indicators 2017, World Bank, Washington, DC, viewed 30 April 2018, from https://data.worldbank.org/products/wdi

World Economic Forum, 2015, The global competitiveness report 2015-2016, WEF, Geneva, viewed 30 April 2018, from http://reports.weforum.org/globalcompetitiveness-report-2015-2016/ 